\title{
Group I mGluR-Mediated Inhibition of Kir Channels Contributes to Retinal Müller Cell Gliosis in a Rat Chronic Ocular Hypertension Model
}

\author{
Min Ji, ${ }^{1,2,4 *}$ Yanying Miao, ${ }^{1,3,4 *}$ Ling-Dan Dong, ${ }^{1,3,4}$ Jie Chen, ${ }^{1,3,4}$ Xiao-Fen Mo, ${ }^{1,2,4}$ Shi-Xiang Jiang, ${ }^{1,3,4}$ Xing-Huai Sun, ${ }^{1,2,4}$ \\ Xiong-Li Yang, ${ }^{1,3,4}$ and Zhongfeng Wang ${ }^{1,3,4}$ \\ ${ }^{1}$ Institutes of Brain Science and ${ }^{2}$ Eye \& ENT Hospital, ${ }^{3}$ Institute of Neurobiology, and ${ }^{4}$ State Key Laboratory of Medical Neurobiology, Fudan University, \\ Shanghai 200032, China
}

Müller cell gliosis, which is characterized by upregulated expression of glial fibrillary acidic protein (GFAP), is a universal response in many retinal pathological conditions. Whether down-regulation of inward rectifying $\mathrm{K}^{+}$(Kir) channels, which commonly accompanies the enhanced GFAP expression, could contribute to Müller cell gliosis is poorly understood. We investigated changes of Kir currents, GFAP and Kir4.1 protein expression in Müller cells in a rat chronic ocular hypertension ( $\mathrm{COH}$ ) model, and explored the mechanisms underlying Müller cell gliosis. We show that Kir currents and Kir4.1 protein expression in Müller cells were reduced significantly, while GFAP expression was increased in $\mathrm{COH}$ rats, and these changes were eliminated by MPEP, a group I metabotropic glutamate receptors (mGluR I) subtype mGluR5 antagonist. In normal isolated Müller cells, the mGluR I agonist (S)-3,5-dihydroxyphenylglycine (DHPG) suppressed the Kir currents and the suppression was blocked by MPEP. The DHPG effect was mediated by the intracellular $\mathrm{Ca}^{2+}$ dependent PLC/IP 3 -ryanodine/PKC signaling pathway, but the cAMP-PKA pathway was not involved. Moreover, intravitreal injection of DHPG in normal rats induced changes in Müller cells, similar to those observed in COH rats. The DHPG-induced increase of GFAP expression in Müller cells was obstructed by $\mathrm{Ba}^{2+}$, suggesting the involvement of Kir channels. We conclude that overactivation of mGluR5 by excessive extracellular glutamate in $\mathrm{COH}$ rats could contribute to Müller cell gliosis by suppressing Kir channels.

\section{Introduction}

Reactivation of glial cells (gliosis) occurs in almost all forms of CNS disorders (Sofroniew, 2005). Specifically, gliosis of Müller cells, a major type of glial cells in the retina, is a common response in a variety of retinal pathological alternations (Bringmann et al., 2006; 2009), which contributes to neurodegeneration (Goureau et al., 1999; Kashiwagi et al., 2001; Tezel et al., 2001; Tezel and Wax, 2003; Bringmann et al., 2009). Müller cell gliosis is characterized by upregulated expression of glial cytoskeletal proteins, glial fibrillary acidic protein (GFAP) and vimentin, and downregulated membrane $\mathrm{K}^{+}$conductance, especially inward rectifying $\mathrm{K}^{+}$channel (Kir) 4.1-mediated currents (Francke et al., 1997,

\footnotetext{
Received March 15, 2012; revised June 27, 2012; accepted July 21, 2012.

Author contributions:X.-H.S. and Z.W. designed research; M.J., Y.M., L.-D.D., J.C., X.-F.M., and S.-X.J. performed research; M.J., Y.M., X.-H.S., X.-L.Y., and Z.W. analyzed data; X.-H.S., X.-L.Y., and Z.W. wrote the paper.

This work was supported by grants from the National Program of Basic Research sponsored by the Ministry of Science and Technology of China (2011CB504602), the National Natural Science Foundation of China (31070966; 30900427; 30973264; 30930034), the Key Research Program of Science and Technology Commissions of Shanghai Municipality (11JC1401200), Research Fund for the Doctoral Program of Higher Education of China (20110071110031), and the Scientific Research Foundation for the Returned Overseas Chinese Scholars, State Education Ministry.

*M.J. and Y.M. contributed equally to this work.

Correspondence should be addressed to either Zhongfeng Wang or Xing-Huai Sun, Institutes of Brain Science and Eye \& ENT Hospital, Institute of Neurobiology and State Key Laboratory of Medical Neurobiology, Fudan University, 138 Yixueyuan Road, Shanghai 200032, China. E-mail: zfwang@fudan.edu.cn or xhsun@shmu.edu.cn.

M. Ji's present address: Department of Ophthalmology, Affiliated Hospital of Nantong University, 20 Xi-Si Road, Nantong, Jiangsu 226001, China.

DOI:10.1523/JNEUROSCI.1291-12.2012

Copyright $\odot 2012$ the authors $\quad 0270-6474 / 12 / 3212744-12 \$ 15.00 / 0$
}

2001; Bringmann et al., 2000; Pannicke et al., 2006). It is well established that inhibition of Müller cell $\mathrm{K}^{+}$channels leads to depolarization of the cell membrane (Pannicke et al., 2000, Bringmann et al., 2002a), which disturbs the characteristic hyperpolarized resting potential of the cell and could result in a loss of its neuron-supportive functions. In experimental glaucoma models and DBA/2J mice, which develop ocular hypertension, GFAP expression in Müller cells was enhanced, suggesting reactivation of the cells (Wang et al., 2000; Woldemussie et al., 2004; Xue et al., 2006; Inman and Horner, 2007; Bolz et al., 2008; Zhang et al., 2009). However, the evidence now available concerning changes in $\mathrm{K}^{+}$channels, following the onset of glaucoma, seems inconsistent. It was reported that Kir currents were downregulated in glial cells isolated from diseased human retinas, including those from patients with glaucoma (Francke et al., 1997). However, no significant alterations of membrane $\mathrm{K}^{+}$channels were detected in DBA/2J mice (Bolz et al., 2008). The first purpose of this investigation was to explore whether Müller cell gliosis is indeed related to Kir channels in experimental glaucoma. We here show that the increased GFAP expression in Müller cells in a rat chronic ocular hypertension $(\mathrm{COH})$ model is accompanied by a progressive, significant reduction of Kir currents and Kir proteins in these cells. We further provide evidence that the increased GFAP expression may be a consequence of reduced activity of Kir channels.

A second question we wanted to address was what caused the changes in Kir channels in experimental glaucoma. Considerable 
A
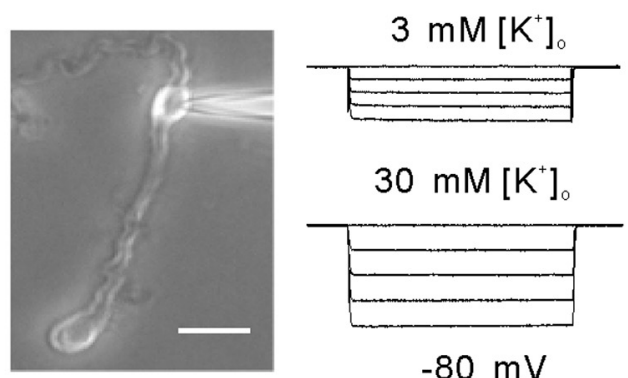

$30 \mathrm{mM}\left[\mathrm{K}^{+}\right]_{0}$

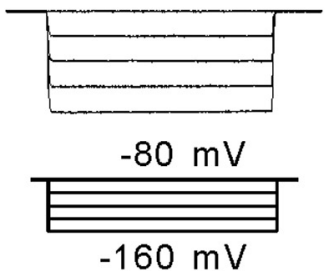

D
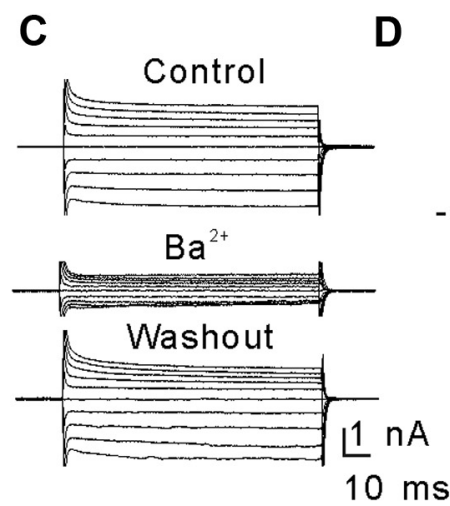

E

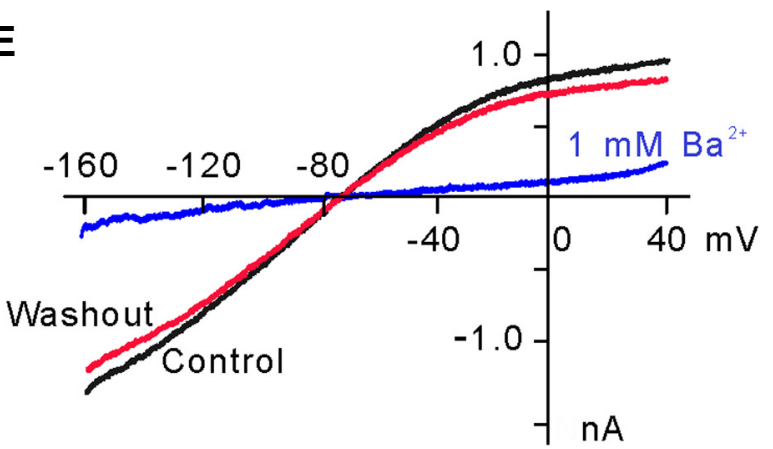

Figure 1. Inwardly rectifying $\mathrm{K}^{+}$-selective current (Kir) in rat retinal Müller cells. A, Micrograph showing a typical isolated rat Müller cell. Scale bar, $10 \mu \mathrm{m} . \boldsymbol{B},\left[\mathrm{K}^{+}\right]_{0}$ dependence of hyperpolarization-activated Kir currents of Müller cells. The currents were evoked by a series of hyperpolarized voltage pulses from a holding potential of $-80 \mathrm{mV}$ in increments of $-20 \mathrm{mV}$. Note that the current amplitudes were increased with an increase in $\left[\mathrm{K}^{+}\right]_{0} . C, \mathrm{Ba}^{2+}(1 \mathrm{~mm})$ blocked the membrane currents of a Müller cell, voltage clamped at $-80 \mathrm{mV}$ and stepped to $-160 \mathrm{mV}$ in $-10 \mathrm{mV}$ increments and then to $+20 \mathrm{mV}$ in $10 \mathrm{mV}$ increments. $\boldsymbol{D}_{\text {, }}$ Membrane currents plotted against the step potentials. Note the $\mathrm{K}^{+}$-selective weakly rectifying Kir4.1-like I-V relationship $(n=$ 10). The Kir currents were reduced significantly by $\mathrm{Ba}^{2+}(1 \mathrm{mM})$. E, Currents elicited by a $1 \mathrm{~s}$ voltage ramp from $-160 \mathrm{mV}$ to +40 $\mathrm{mV}$ before (control), after the application of $\mathrm{Ba}^{2+}(1 \mathrm{~mm})$ and washout of $\mathrm{Ba}^{2+}$.

evidence suggests that excess extracellular glutamate, a major excitatory neurotransmitter in the mammalian retina, may be an important risk factor for retinal injury in glaucoma due to overactivation of both ionotropic and metabotropic glutamate receptors (mGluRs) (Salt and Cordeiro, 2006; Seki and Lipton, 2008). Overactivation of mGluRs has been shown to contribute to pathogenesis of various CNS disorders (Nicoletti et al., 1999; Lau and Tymianski, 2010; Caraci et al., 2012). Our data show that overactivation of group I mGluR (mGluR I) may be involved in Müller cell gliosis in the rat $\mathrm{COH}$ model via inhibiting Kir channels, a condition that could be ameliorated by suppressing these receptors.

\section{Materials and Methods}

Animals and rat $\mathrm{COH}$ model. All experimental procedures described here were in accordance with the National Institutes of Health (NIH) guidelines for the Care and Use of Laboratory Animals and the guidelines of Fudan University on the ethical use of animals. During this study, all possible efforts were made to minimize the number of animals used and their suffering. Male Sprague Dawley rats, weighing $100-300 \mathrm{~g}$ and obtained from SLAC Laboratory Animal Company, were housed under conditions of a $12 \mathrm{~h}$ light/dark cycle. The rat $\mathrm{COH}$ model was reproduced following a procedure described previously in detail (Naka et al., 2010; Wu et al., 2010; Chen et al., 2011). Briefly, rats were anesthetized with an intramuscular injection of a mixture of ketamine $(25 \mathrm{mg} / \mathrm{kg})$ and xylazine $(10 \mathrm{mg} / \mathrm{kg})$, and the eyes were further anesthetized locally with a topical application of $0.4 \%$ oxybuprocaine hydrochloride eye drops (Benoxil, Santen Pharmaceutical). Two or three episcleral veins in the left eye were carefully separated and cauterized under an OPMI VISU 140 microscope (Carl Zeiss). In sham-operated control eyes, the surgery was done using a similar procedure, except for not occluding the vines. As a convention, sham-operation was done on the eyes of other rats, but not on the contralateral eye of the operated animal. After surgery, the eyes were flushed with antibiotic eye drops and covered with antibiotic ointment. Intraocular pressure (IOP) was measured using a handheld digital tonometer (Tonopen XL; Mentor $\mathrm{O} \& \mathrm{O}$ ), under general and local anesthesia as described above. The average value of five consecutive acceptable measurements with a deviation $<5 \%$ was recorded. All measurements were performed in the morning to avoid possible circadian differences. The IOPs of both eyes were measured before surgery as a baseline, immediately after surgery (day 0 ), the first day after surgery (G1d), and weekly thereafter.

Preparation of isolated Müller cells. Animals were deeply anesthetized with $4 \%$ sodium pentobarbital and killed by decapitation. Retinas were removed quickly and incubated in oxygenated Hank's solution containing the following (in mM): $\mathrm{NaCl}$ 137, $\mathrm{NaHCO}_{3} 0.5$, $\mathrm{NaH}_{2} \mathrm{PO}_{4} 1, \mathrm{KCl} 3, \mathrm{CaCl}_{2} 2, \mathrm{MgSO}_{4} 1$, HEPES 20 , sodium pyruvate 1 , and glucose 16 , adjusted to $\mathrm{pH} 7.4$ with $\mathrm{NaOH}$. The retinas were then digested with $1.6 \mathrm{U} / \mathrm{ml}$ papain (Worthington Biochemical) in Hank's solution supplemented with $0.2 \mathrm{mg} / \mathrm{ml} \mathrm{L}$-cysteine and 0.2 $\mathrm{mg} / \mathrm{ml}$ bovine serum albumin, for $35 \mathrm{~min}$ at $35^{\circ} \mathrm{C}$. The solution was bubbled continuously with $100 \% \mathrm{O}_{2}$ and adjusted to $\mathrm{pH} 7.4$ with $\mathrm{NaOH}$. After several rinses with Hank's solution, the retinas were mechanically dissociated with fire-polished Pasteur pipettes, and the cell suspension was plated onto a culture dish mounted on an inverted microscope (IX 70; Olympus Optical). Müller cells with typical morphological features (Ishii et al., 1997; Wurm et al., 2006) were chosen for whole-cell patchclamp recording within $2-3 \mathrm{~h}$ after dissociation.

Whole-cell patch-clamp recordings. Dissociated Müller cells were continuously perfused with an external solution containing the following (in $\mathrm{mm}$ ): $\mathrm{NaCl} 135, \mathrm{KCl} 3, \mathrm{CaCl}_{2} 2, \mathrm{MgCl}_{2} 1$, HEPES 10, glucose 11, pyruvate sodium 1, TTX 0.0005 , and sucrose 10 , adjusted to $\mathrm{pH} 7.4$ with $\mathrm{NaOH}$. 
Patch pipettes were made by pulling BF150-86-10 glass (Sutter Instrument Co.) on a P-97 flaming/brown micropipette puller (Sutter Instrument Co.) and fire polished (Model MF-830; Narishige) for recording. The pipette resistance was typically $8-10 \mathrm{M} \Omega$ after filling with an internal solution consisting of (in $\mathrm{mM}$ ): $\mathrm{NaCl} 20$, K-gluconate $130, \mathrm{CaCl}_{2} 1$, $\mathrm{MgCl}_{2}$ 2, EGTA 1, HEPES 10, GTP-Na 0.1, and ATP-Mg 2, adjusted to pH 7.2 with $\mathrm{KOH}$ and to $290-300 \mathrm{mOsm} / \mathrm{L}$. Whole-cell membrane currents were recorded from Müller cells using an Axopatch 200B amplifier, Digidata 1322A data acquisition board, and Clampex 8.0 software (Molecular Devices). Fast capacitance was fully cancelled and cell capacitance was partially cancelled as much as possible by the amplifier circuits. Seventy percent of the series resistance of the recording electrode was compensated. Analog signals were sampled at $5 \mathrm{kHz}$, filtered at $1 \mathrm{kHz}$, and stored for further analysis. All recordings were made at room temperature $\left(20-25^{\circ} \mathrm{C}\right)$.

Intravitreal injection. Rats were anesthetized with an intramuscular injection of a mixture of ketamine and xylazine. The pupil was dilated with tropicamide drops, and $10 \mu \mathrm{M}(S)$-3,5-dihydroxyphenylglycine (DHPG), $10 \mu \mathrm{M}$ MPEP, $200 \mu \mathrm{M} \mathrm{BaCl}_{2}$, or $50 \mu \mathrm{M} \mathrm{CoCl}$ dispersed in $2 \mu \mathrm{l}$ of $0.9 \%$ saline were injected into the vitreous space through a postlimbus spot using Hamilton microinjector (Hamilton) under a stereoscopic microscope (Carl Zeiss). A 30-gauge needle was inserted $2 \mathrm{~mm}$ behind the temporal limbus and directed toward the optic nerve. Eyes that received only an injection of saline in the same manner served as a vehicle control.

Western blot analysis. Western blot analysis was conducted as previously described with some modifications (Zhao et al., 2010; Chen et al., 2011). Rat retinas were lysed in lysis buffer ( $50 \mathrm{~mm}$ Tris-Cl, $150 \mathrm{~mm} \mathrm{NaCl}$, $1 \%$ Triton X-100, 0.1\% aprotinin, $1 \mathrm{~mm}$ phenylmethylsulfonyl fluoride, $1 \mathrm{~mm}$ sodium orthovanadate, and $25 \mathrm{~mm}$ sodium fluoride, $\mathrm{pH}$ 7.4), and protein concentrations were determined by the BCA method (Pierce). Protein samples $(1.0 \mu \mathrm{g} / \mu \mathrm{l}, 15 \mu \mathrm{l})$ were subjected to $10 \%$ SDS-PAGE using a Mini-Protean 3 electrophoresis system (Bio-Rad) and electrotransferred to polyvinylidene fluoride membranes using a Mini TransBlot electrophoretic transfer system (Bio-Rad). The membranes were blocked with $5 \%$ skimmed milk at room temperature for $1 \mathrm{~h}$, and then incubated with mouse monoclonal antibody against GFAP (1:1000 dilution; Sigma), rabbit polyclonal antibody against Kir4.1 (1:400 dilution; Alomone) or mouse monoclonal antibody against $\beta$-actin (1:2000, Sigma) overnight at $4^{\circ} \mathrm{C}$. The blots were washed with TBST and incubated with HRP-conjugated goat anti-mouse or anti-rabbit IgG (1:4000; Jackson ImmunoResearch Laboratories) for $1 \mathrm{~h}$ at room temperature and visualized with enhanced chemofluorescence reagent (Pierce). For sequential immunoblotting, the blots were reblocked, tested for residual signal, and then stripped with restore Western blot stripping buffer (Pierce) if necessary. The protein bands were quantitatively analyzed with NIH image analysis software.

Immunohistochemistry. Immunofluorescent staining was performed following the procedure described in detail previously (Zhao et al., 2010; Yang et al., 2011). After rats were anesthetized and perfused with $4 \%$ paraformaldehyde (PFA, in $0.1 \mathrm{M} \mathrm{PB}, \mathrm{pH} 7.4$ ), the left eyeballs were removed and post-fixed in $4 \% \mathrm{PFA}$ for $2-4 \mathrm{~h}$, followed by dehydration with graded sucrose solutions at $4^{\circ} \mathrm{C}(4 \mathrm{~h}$ in $20 \%$ and overnight in $30 \%)$. The retinas were vertically sectioned at $14 \mu \mathrm{m}$ thickness on a freezing microtome (Leica). The slices were collected and mounted on chromealum-gelatin-coated slides. After washing with $0.01 \mathrm{M} \mathrm{PBS,} \mathrm{pH} \mathrm{7.4,} \mathrm{the}$ sections were blocked in $6 \%$ bovine serum albumin (Sigma) in PBS plus $0.1 \%$ Triton X-100 at room temperature for $2 \mathrm{~h}$, and then incubated with mouse monoclonal anti-GFAP (1:400 dilution; Sigma), polyclonal rabbit anti-Kir4.1 (1:400 dilution; Alomone) primary antibodies at $4^{\circ} \mathrm{C}$ for $48 \mathrm{~h}$. Immunoreactive proteins were visualized by incubating with FITCconjugated goat anti-mouse IgG (1:200 dilution; Jackson ImmunoResearch Laboratories) and cy3-conjugated goat anti-rabbit IgG (1:200 dilution; Jackson ImmunoResearch Laboratories). The samples were mounted with anti-fade mounting medium with DAPI (Vector Laboratories) and the immunofluorescence images were visualized with an Olympus FV1000 confocal laser-scanning microscope using a 40× oilimmersion objective lens. To avoid any possible reconstruction stacking artifact, the double labeling was precisely evaluated by sequential scanning of single-layer optical sections at intervals of $1.0 \mu \mathrm{m}$.
A
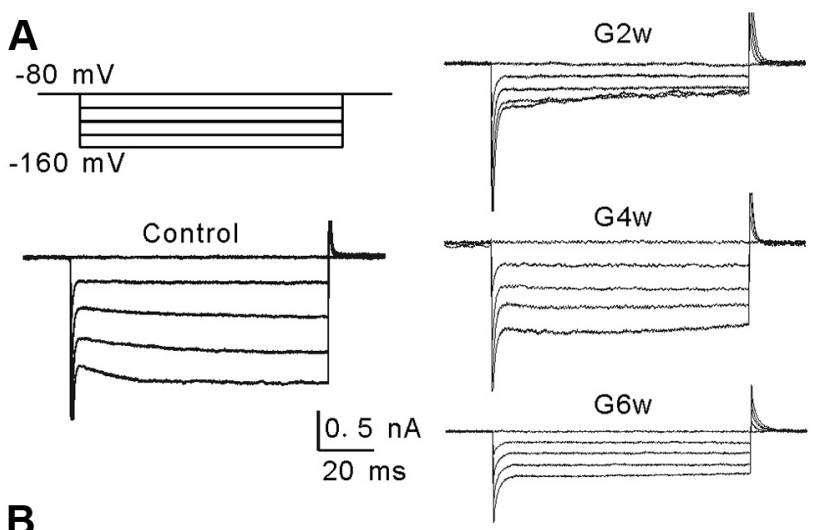

B
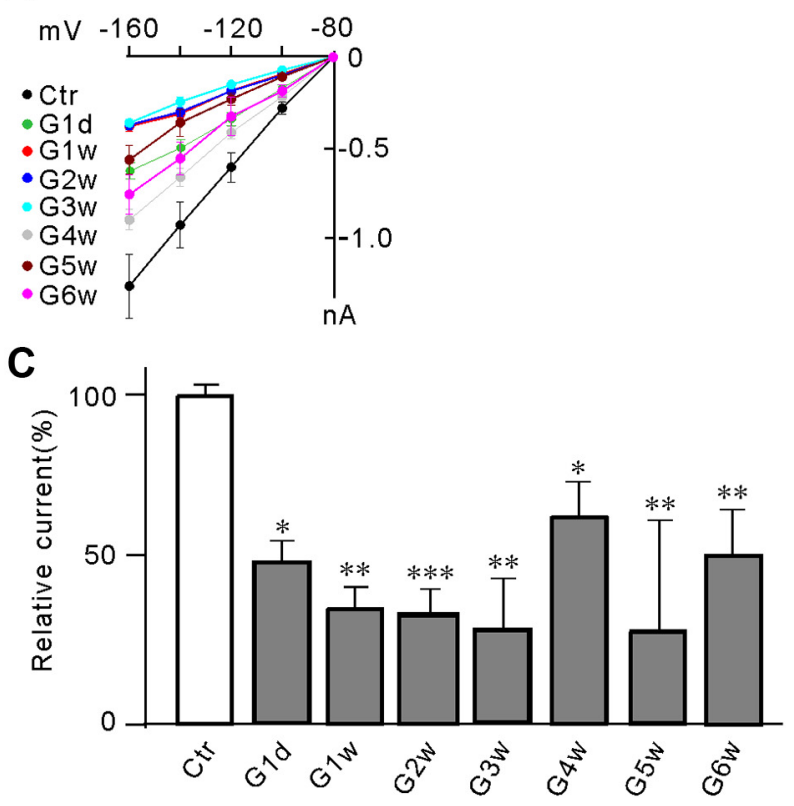

Figure 2. Suppression of Kir currents in Müller cells in a rat $\mathrm{COH}$ model. $\boldsymbol{A}$, Voltage-clamp analysis of the Kir current changes at negative membrane potentials. Cells were clamped at $-80 \mathrm{mV}$ and stepped to $-160 \mathrm{mV}$ in $-20 \mathrm{mV}$ increments (top left). Whole-cell membrane currents were recorded in Müller cells isolated from sham-operated control (Ctr) and $\mathrm{COH}$ rats on the second (G2w), fourth (G4w), and sixth week (G6w) after the operation. $\boldsymbol{B}$, The I-V relationships, showing voltage-dependent suppression of Kir current amplitudes in Müller cells obtained from $\mathrm{Ctr}$ and $\mathrm{COH}$ rats at the first day after surgery (G1d), and the first to sixth week (G1W-G6W) after the operation C, Summarized data showing that the average Kir current peak amplitudes decreased when the IOP was elevated. All data are normalized to control. Error bars represent SEM. $n=8 \sim 15,{ }^{*} p<0.05,{ }^{* *} p<0.01$, and ${ }^{* * *} p<0.001$ versus control (Ctr).

Reagents and drug application. KN-62, KN-93, U73122, MPMQ, and MPEP were obtained from Tocris Bioscience. All the other chemicals were from Sigma-Aldrich. U73122, chelerythrine chloride, Bis IV, MPMQ, MPEP, and forskolin were first dissolved in dimethyl sulfoxide (DMSO) and then added to the extracellular or internal solution, with the final concentration of DMSO being $<0.1 \%$. The other chemicals were freshly dissolved in the extracellular or internal solution. Drugs were delivered by a superfusion drug application system (DAD-8VCSP, ALA Scientific Instruments), which has eight pressurized $5 \mathrm{ml}$ reservoirs, each with its own control valve to feed fluid through an eight-to-one tubing manifold (500 $\mu \mathrm{m}$ inner diameter; ALA Scientific Instruments). The open/close switch of each valve was manually controlled. Once the valve was open, the solution in the corresponding reservoir was pressure ejected by nitrogen gas along the pipes. With the large flow pipes, $10-$ $90 \%$ whole-cell solution exchanges were achieved in $<2.5 \mathrm{~ms}$.

Data analysis. The data analysis was performed using Clampfit 8.0 (Molecular Devices) and Igor 4.0 (WaveMetrics). Data are presented as means \pm SEM. A one-way ANOVA with Bonferroni's post hoc test (mul- 

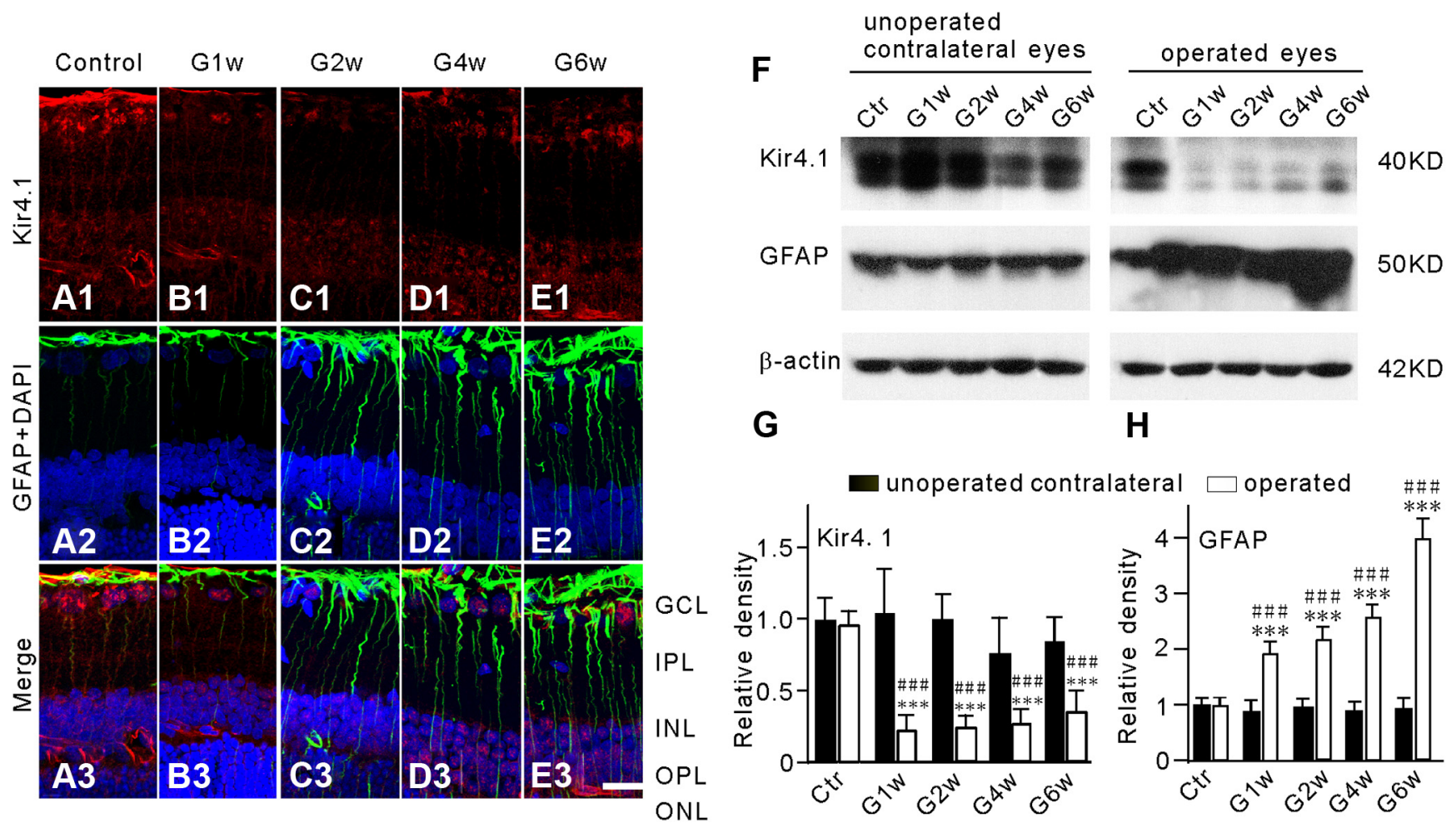

Figure 3. Changes in Kir4.1 and GFAP expression in Müller cells of $\mathrm{COH}$ rats. A1-E1, Immunofluorescence labeling showing the changes in Kir4.1 protein expression in rat retinal vertical slices taken from sham-operated retina (Control), and those obtained at the first (G1w), second (G2w), fourth (G4w), and sixth week (G6w) after the operation. Note that Kir4.1 expression in the endfeet of Müller cells was reduced in the $\mathrm{COH}$ retinal sections $(\boldsymbol{B 1}, \mathbf{C 1}, \mathbf{D 1}, \mathbf{E 1})$. $\mathbf{A 2}-\mathbf{E 2}$, Immunohistochemical staining showing DAPI and GFAP protein expression in the same slices as shown in $\boldsymbol{A 1}, \boldsymbol{B 1}$, $\boldsymbol{C 1}$, $\mathbf{D 1}$, and $\boldsymbol{E 1}$, respectively. (3-E3, Merged images of $\boldsymbol{A} \mathbf{1}-\boldsymbol{E 1}$ and $\boldsymbol{A 2}-\mathbf{E 2}$. Scale bar, (for all the images) $20 \mu \mathrm{m}$. IPL, Inner plexiform layer; INL, inner nuclear layer; ONL, outer nuclear layer. $\boldsymbol{F}$, Representative immunoblots showing the changes in Kir4.1 (top) and GFAP (middle) protein expression in sham-operated (Ctr) and COH retinal extracts obtained from both operated eyes and their unoperated contralateral eyes in the same rats at different time points (G1w, G2w, G4w, and G6w) after the operation. $\mathbf{G}, \boldsymbol{H}$, Bar charts summarizing the average densitometric quantification of immunoreactive bands of Kir4.1 $(\boldsymbol{G})$ and GFAP $(\boldsymbol{H})$ protein expression at different time points after the operation. All data are normalized to control (Ctr). $n=6$ all groups. ${ }^{* * *} p<0.001$ versus the unoperated contralateral eyes in the same rats, and ${ }^{\# \#} p<0.001$ versus $C$ tr.

tiple comparisons), Mann-Whitney test (comparisons between two groups), and $t$ test (paired data) were used as appropriate. A value of $p<$ 0.05 was considered significant.

\section{Results}

\section{Suppression of Kir currents in the rat $\mathrm{COH}$ model}

Kir currents were first identified in isolated rat Müller cells (Fig. $1 A$ ). The currents, induced in a Müller cell by a series of hyperpolarized voltage pulses from a holding potential of $-80 \mathrm{mV}$ in increments of $-20 \mathrm{mV}$ at different concentrations of extracellular potassium $\left(\left[\mathrm{K}^{+}\right]_{\mathrm{o}}\right)$, are shown in Figure $1 B$. The channels opened rapidly and did not inactivate when hyperpolarization was maintained. The currents were increased in amplitudes with increasing $\left[\mathrm{K}^{+}\right]_{\mathrm{o}}$. Figure $1 C$ shows that bath application of $\mathrm{Ba}^{2+}$ (1 mM) significantly suppressed the currents from a Müller cell, induced by stepping to test potentials between -160 to $+20 \mathrm{mV}$ from a holding potential of $-80 \mathrm{mV}$, in a reversible manner, and the average data $(n=10)$ are plotted in Figure $1 D$. Consistently, bath application of $\mathrm{Ba}^{2+}$ yielded similar effects on ramp currents recorded from another Müller cell (Fig. $1 E$ ), and addition of Cs ${ }^{+}$ ( $1 \mathrm{~mm}$ ) did not further suppress the current in the presence of $\mathrm{Ba}^{2+}$ (data not shown). These properties of the currents are characteristic of $\mathrm{K}^{+}$-selective Kir currents (Newman, 1993; Iandiev et al., 2006; Wurm et al., 2006). Moreover, the $I-V$ relationships of the currents, shown in Figure 1, D and $E$, exhibited a weakly inward rectifying feature, suggesting that these currents may be largely mediated by Kir4.1 channels (Tada et al., 1998; Kofuji et al., 2002; Butt and Kalsi, 2006).
We then examined whether Kir currents of Müller cells were changed in the COH model (Naka et al., 2010; Chen et al., 2011; Wu et al., 2010). In this model, the average IOP of the operated eyes was sharply increased to $30.0 \pm 0.3 \mathrm{mmHg}$ on G1d $(n=39$, $p<0.001)$ from $19.2 \pm 0.2 \mathrm{mmHg}$ before surgery $(n=39)$. The IOP was declined to $27.5 \pm 0.4 \mathrm{mmHg}$ on the first weak after surgery (G1w, $n=39, p<0.001)$ and then maintained at higher levels during the next 5 weeks $(27.0 \pm 0.4 \mathrm{mmHg}$ on $\mathrm{G} 2 \mathrm{w}, n=32$; $26.8 \pm 0.3 \mathrm{mmHg}$ on G3w, $n=27 ; 26.6 \pm 0.3 \mathrm{mmHg}$ on G4w, $n=23 ; 26.7 \pm 0.4 \mathrm{mmHg}$ on $\mathrm{G} 5 \mathrm{w}, n=18 ; 26.2 \pm 0.5 \mathrm{mmHg}$ on G6w, $n=10 ; p<0.001)$. Meanwhile, the average IOPs in the sham-operated eyes kept unchanged during 6 weeks after surgery, ranging from $19.3 \pm 0.2 \mathrm{mmHg}$ to $20.0 \pm 0.2 \mathrm{mmHg}(n=$ $10 \sim 39$ ), which were not significantly different from that before surgery $(19.4 \pm 0.2 \mathrm{mmHg}, n=39)(p>0.05)$. Kir currents of Müller cells isolated from the operated eyes and the shamoperated eyes were recorded at different time points, using stepping voltages. Figure 2, $A$ and $B$, show the currents recorded from representative cells and the averaged $I-V$ relationships, respectively. The averaged current amplitudes by voltage steps of -160 $\mathrm{mV}$ are represented as a function of time after the operation in Figure $2 C$. It is evident that the currents were reduced in amplitudes at all time points. The peak current amplitudes were decreased to approximately $47 \%$ of control even on G1d $(47.8 \pm$ $4.5 \%$ control, $n=8, p=0.018)$, then further to $36.3 \pm 7.4 \%$ of control on G1w ( $n=8, p=0.008)$, and remained at this level for next 2 weeks (G2w: $33.4 \pm 7.9 \%, n=12, p<0.001$; G3w: $28.5 \pm$ 
$16.5 \%$ of control, $n=8, p=0.003)$. Although the reduction of the current amplitudes became less significant on G4w (63.7 \pm $10.4 \%$ of the control, $n=8, p=0.024)$ and on G6w (51.9 \pm $14.1 \%$ of control, $n=11, p=0.004)$, they were still lower than control (Fig. 2C).

\section{Kir4.1 and GFAP expression in the $\mathrm{COH}$ model}

We further evaluated changes in Kir4.1 protein and GFAP protein expression in our $\mathrm{COH}$ model by immunohistochemistry and Western blotting. Figure $3 A 1$ shows that in sham-operated retinal section (Control), Kir4.1 proteins were extensively expressed in Müller cells, predominantly at the endfeet, in cells of the ganglion cell layer (GCL) and the outer plexiform layer (OPL), and in the perivascular membranes. GFAP proteins were seen mainly at the endfeet of Müller cells (Fig. 3A2,3), which is consistent with previous reports (Kofuji et al., 2002; Iandiev et al., 2006; Wurm et al., 2006). Kir4.1 expression in Müller cells, especially at the endfeet, showed a remarkable reduction in retinal sections obtained at different times (G1w-G6w) from the $\mathrm{COH}$ rats (Fig. 3B1,C1,D1,E1). Consistently, total Kir4.1 proteins extracted from the operated eyes in the $\mathrm{COH}$ retinas detected by Western blot were significantly decreased, as illustrated in the representative results in Figure 3F. The protein level of Kir4.1 was greatly reduced to $22.6 \pm 10.6 \%$ of control on G1w $(n=6, p<$ 0.001 vs values obtained from sham-operated control eyes and unoperated contralateral eyes of the same rats), and it remained at this low level until G6w (24.6 $\pm 9.3 \%$ on G2w, $n=6 ; 27.1 \pm$ $11.4 \%$ on G4w, $n=6 ; 35.5 \pm 16.1 \%$ of control on G6w, $n=6$; $p<0.001$ vs values obtained from sham-operated control eyes and unoperated contralateral eyes of the same rats, respectively) (Fig. 3G). Meanwhile, immunocytochemical experiments showed that GFAP expression in Müller cells was progressively enhanced in association with the elevated IOP (Fig. 3B2-E2), suggesting Müller cells gliosis. Consistent with this, Western blot experiments (Fig. $3 F$ ) showed that the average densities of GFAP proteins were considerably increased to $196.0 \pm 21.5 \%(n=6), 219.4 \pm 24.1 \%(n=6)$, $260.1 \pm 23.3 \%(n=6)$, and $400.3 \pm 36.6 \%$ of control $(n=6)(p<$ 0.001 vs the values of sham-operated control and unoperated contralateral eyes of the same rats) on G1w, G2w, G4w, and G6w, respectively (Fig. $3 H$ ).

\section{Activation of mGluR I inhibits Kir currents of isolated Müller cells}

What caused the reduction of Kir currents in the $\mathrm{COH}$ model? It was previously demonstrated that L-glutamate acted at mGluRs to inhibit outward $\mathrm{K}^{+}$currents in isolated salamander Müller cells (Schwartz, 1993). Moreover, as the glutamate transporter levels were reduced significantly in glaucoma models, it has been suggested that the glutamate concentrations in the retina might have increased (Dreyer et al., 1996; Vorwerk et al., 2000; Martin et al., 2002; Guo et al., 2006; Salt and Cordeiro, 2006; Harada et al., 2007; Seki and Lipton, 2008). We therefore proposed a working hypothesis that increased extracellular glutamate in experimental glaucoma may overactivate mGluR I, thereby inhibiting Kir currents. This hypothesis was tested by examining effects of mGluR I agonist and antagonist on Kir currents. As shown in Figure 4A, the selective mGluR I agonist DHPG $(10 \mu \mathrm{M})$ significantly and voltage-dependently inhibited Kir currents in isolated rat retinal Müller cells in a reversible manner. Figure $4 B$ shows the DHPG action as a function of time. Bath application of DHPG $(10 \mu \mathrm{M})$ rapidly decreased the Kir current peak amplitudes to $39.1 \pm 5.9 \%$ of pretreatment levels in $200 \mathrm{~s}(n=6, p<0.001)$, and they then recovered gradually with normal bath solution washout. The
A
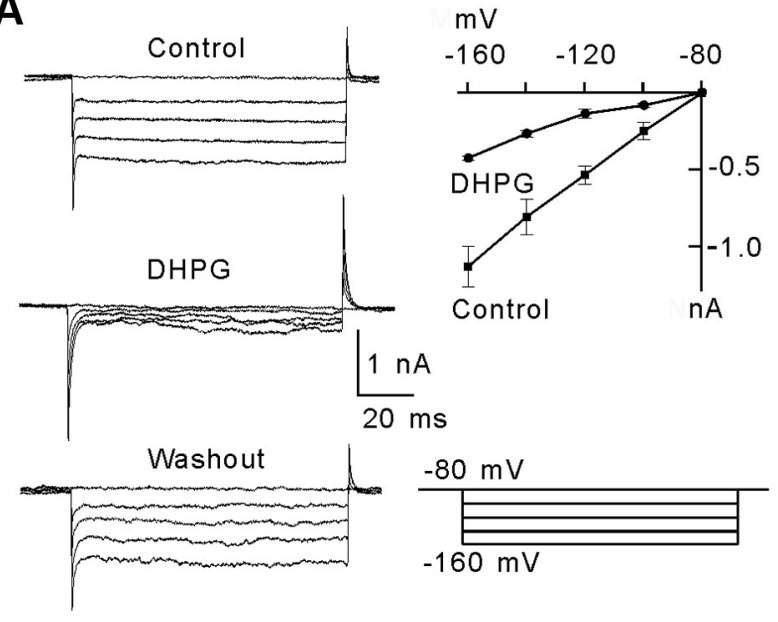

B

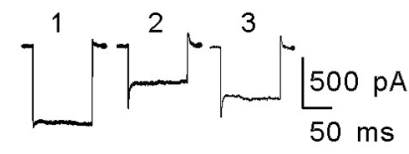

C
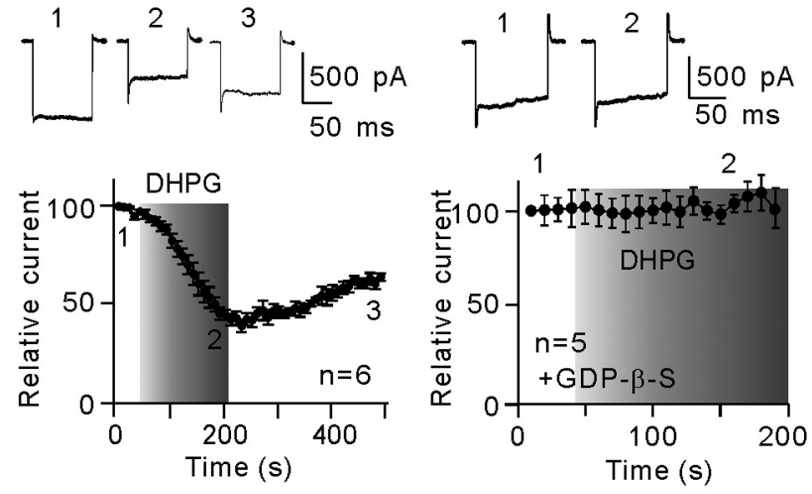

D

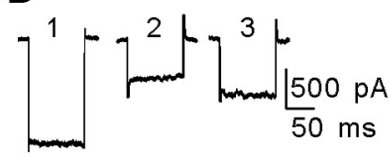

E
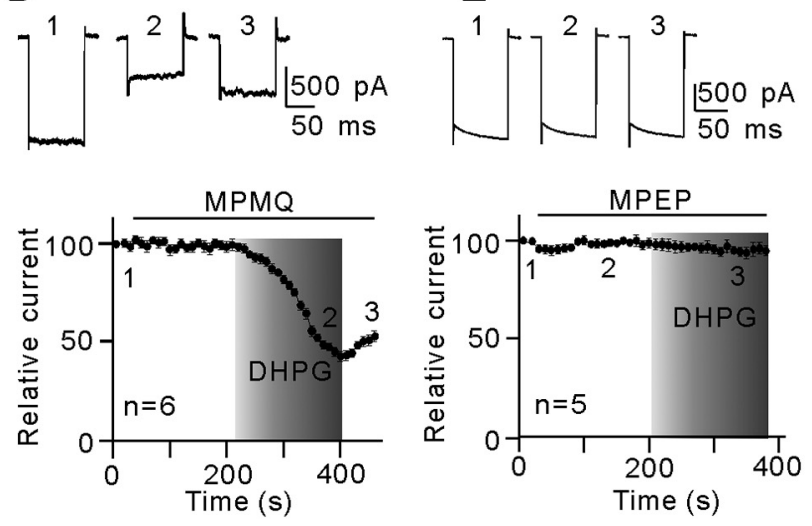

Figure 4. Activation of mGluR I suppresses Kir currents in Müller cells. $\boldsymbol{A}, \mathrm{DHPG}(10 \mu \mathrm{m})$, a selective mGluR I receptor agonist, inhibited remarkably and reversibly Kir currents. The currents were evoked by a series of pulses from a holding potential of $-80 \mathrm{mV}$ to $-160 \mathrm{mV}$ in $-20 \mathrm{mV}$ increments. The $I-V$ relationships show voltage-dependent reduction in Kir current amplitudes. $n=10$. $\boldsymbol{B}$, Plot of Kir inward currents evoked by a voltage step from a holding potential of $-80 \mathrm{mV}$ to $-160 \mathrm{mV}$ as a function of time, showing that DHPG $(10 \mu \mathrm{m})$ significantly suppressed the Kir current amplitudes. $n=6$. The representative current traces (top) are taken from the time points as indicated. $C$, Internal dialysis of GDP- $\beta-S(3 \mathrm{~mm})$ prevented the DHPG-induced suppression of Kir currents. The representative current traces (top) are used to generate the plot. $n=5$. D, Plot of Kir inward currents as a function of time, showing that preperfusion of MPMQ (10 $\mu \mathrm{M})$ failed to block DHPG-induced reduction in Kir current amplitudes. $n=6$. The representative current traces (top) are taken from the time points as indicated. $\boldsymbol{E}$, Plot of Kir inward currents as a function of time, showing that preperfusion of MPEP (10 $\mu \mathrm{m})$ blocked DHPG-induced reduction in Kir current amplitudes. $n=5$. The representative current traces (top) are taken from the time points as indicated. All the current amplitudes are normalized to the amplitude of the first evoked event. 

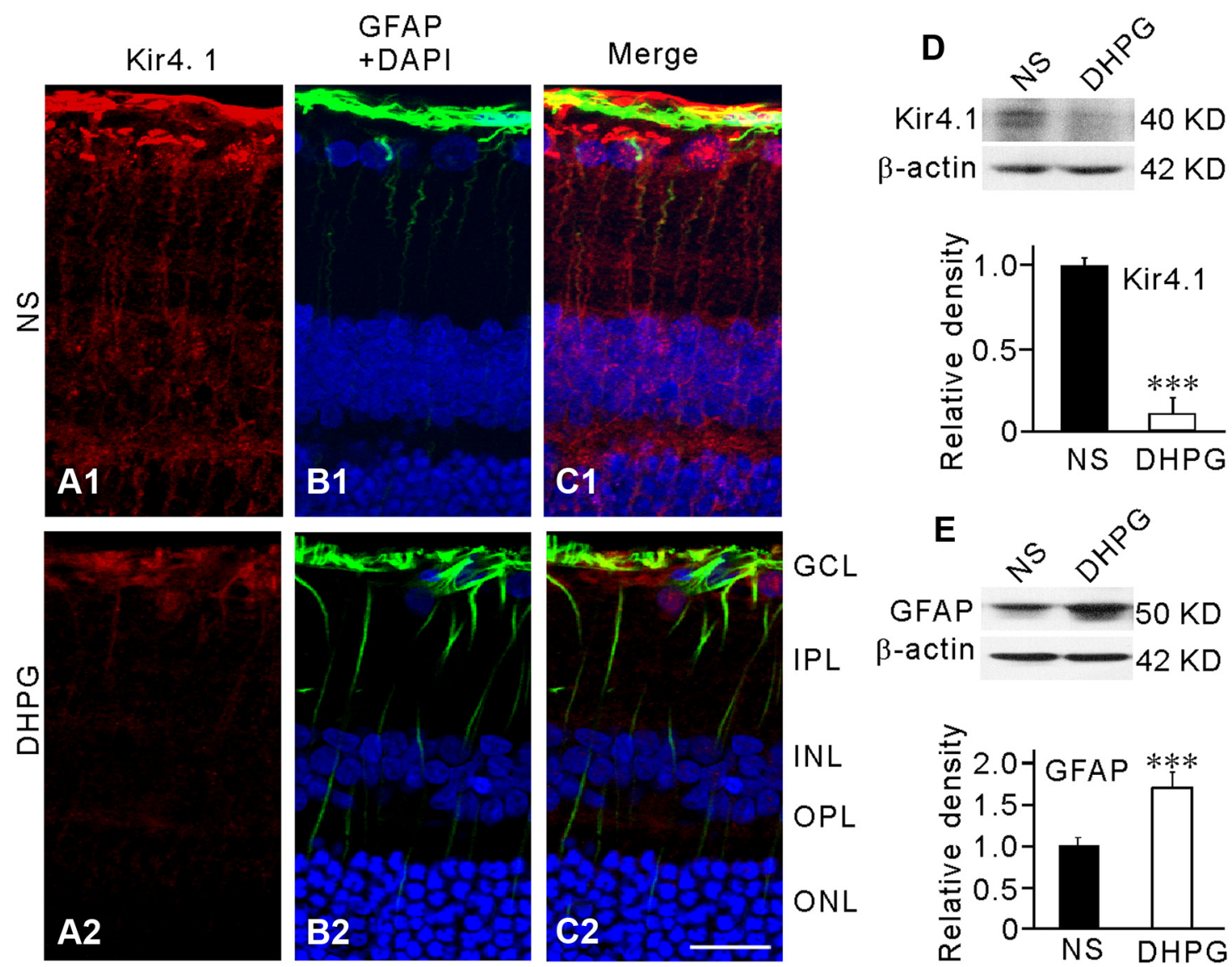

Figure 5. DHPG decreases Kir4.1 protein expression and induces GFAP expression in Müller cells. DHPG (10 $\mu \mathrm{m})$ or vehicle $(0.9 \%$ saline, NS) were injected into the vitreous space in a volume of $2 \mu$ l. The retinas were sectioned 2 weeks after the injection. $\boldsymbol{A} \mathbf{1}, \mathbf{A 2}$, Immunofluorescence labeling showing the Kir4. 1 protein expression in retinal vertical slices taken from the NS- (A1) or the DHPG-

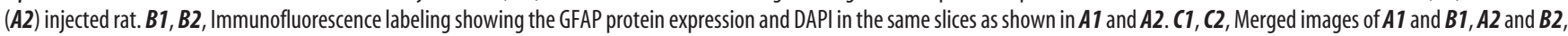
respectively. Scale bar, $20 \mu \mathrm{m}$. D, Representative Western blot analysis showing the Kir4.1 protein expression in the NS- and DHPG-injected eyes (top). Bar chart summarizing the Kir4.1 protein expression in the NS- and DHPG-injected eyes (below). $n=6,{ }^{* * *} p<0.001$ versus NS. $\boldsymbol{E}$, Representative Western blot analysis showing the GFAP protein expression in the NS- and DHPG-injected eyes (top). Bar chart summarizing the GFAP protein expression in the NS- and DHPG-injected eyes (below). $n=6,{ }^{* * *} p<0.001$ versus NS. All data were normalized to those obtained in the NS eyes.

DHPG effect was blocked by an intracellular dialysis of GDP- $\beta$-S (3 $\mathrm{mM})$, a $\mathrm{G}$ protein inhibitor, through recording pipettes. During GDP- $\beta$-S dialysis, as shown in Figure $4 C$, bath application of $10 \mu \mathrm{M}$ DHPG for $200 \mathrm{~s}$ had no effect on the Kir currents. The average peak current amplitudes in the presence of DHPG for 200 s were $98.2 \pm 4.7 \%$ of the control levels $(n=5, p=0.98)$. As mGluR I consists of two receptor subtypes, mGluR1 and mGluR5, to explore which one or whether both were involved in the DHPG effect, we used selective antagonists for these two subtypes. When isolated Müller cells were preincubated with MPMQ, a selective mGluR1 antagonist, $10 \mu \mathrm{M}$ DHPG persisted to inhibit Kir currents in the presence of MPMQ. Bath application of DHPG for $200 \mathrm{~s}$ reduced the current amplitudes to $43.0 \pm 2.8 \%$ of that before DHPG application $(n=6, p<0.001)$ (Fig. $4 D)$. In contrast, preincubation with $10 \mu \mathrm{M}$ MPEP, a highly selective mGluR5 antagonist, almost completely eliminated the DHPG effect. In the presence of MPEP, Kir current amplitudes were hardly changed by $10 \mu \mathrm{M}$ DHPG $(94.5 \pm 2.6 \%$ of control, $n=5, p=0.97)$ (Fig. $4 E)$. These results suggest that it was mGluR5, but not mGluR1, that was involved in the DHPG effect on Kir currents.

Changes in Kir and GFAP expression by activation of mGluR I receptor

How activation of mGluR I change the expression of Kir and GFAP was studied by immunohistochemistry and Western blot- ting. DHPG of $10 \mu \mathrm{M}(2 \mu \mathrm{l})$ was first intravitreally injected into left eyes, and after 2 weeks retinal slices and extracts were made for immunohistochemistry and Western blot analysis. As shown in Figure 5, A2 and C2, Kir4.1 expression in Müller cells was remarkably decreased, as compared with those of normal saline (NS)-injected retinas (Fig. 5A1,C1). Similar observations were obtained in other five rats. Western blotting revealed that total Kir4.1 protein in DHPG-injected retinas was profoundly decreased to $10.8 \pm 9.7 \%$ of NS-injected group $(n=6, p<0.001$; Fig. 5D). Meanwhile, DHPG injection induced a much stronger GFAP expression in Müller cells (Fig. 5B2,C2), as compared with that observed in normal ones (Fig. 5B1,C1). Western blotting indicated that total GFAP protein was increased to $172.4 \pm 15.0 \%$ of NS-injected retinas $(n=6, p<0.001$; Fig. $5 E)$, following DHPG injection. These changes in Kir and GFAP expression caused by activation of mGluR I were reminiscent of those observed in the $\mathrm{COH}$ model.

To address the question whether the DHPG-induced increase in GFAP expression in normal retina could be a consequence of reduced activity of Kir channels, we examined effects of DHPG on GFAP expression in Müller cells in normal retina when Kir channels were blocked by $\mathrm{Ba}^{2+} . \mathrm{BaCl}_{2}(200 \mu \mathrm{M})$ was intravitreally injected $1 \mathrm{~d}$ before DHPG $(10 \mu \mathrm{M})$ injection. Five days after DHPG injection, expression of GFAP in retinal slices was examined by immunohistochemistry and retinal extracts by Western 

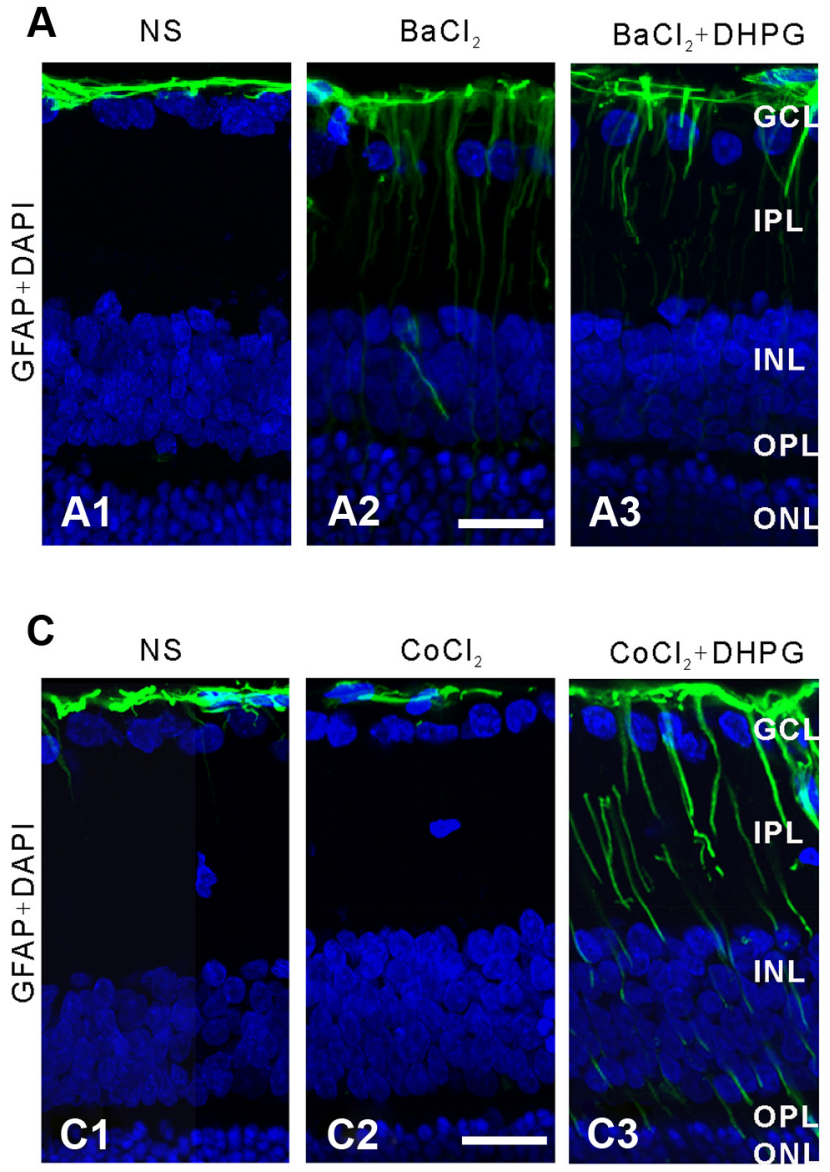

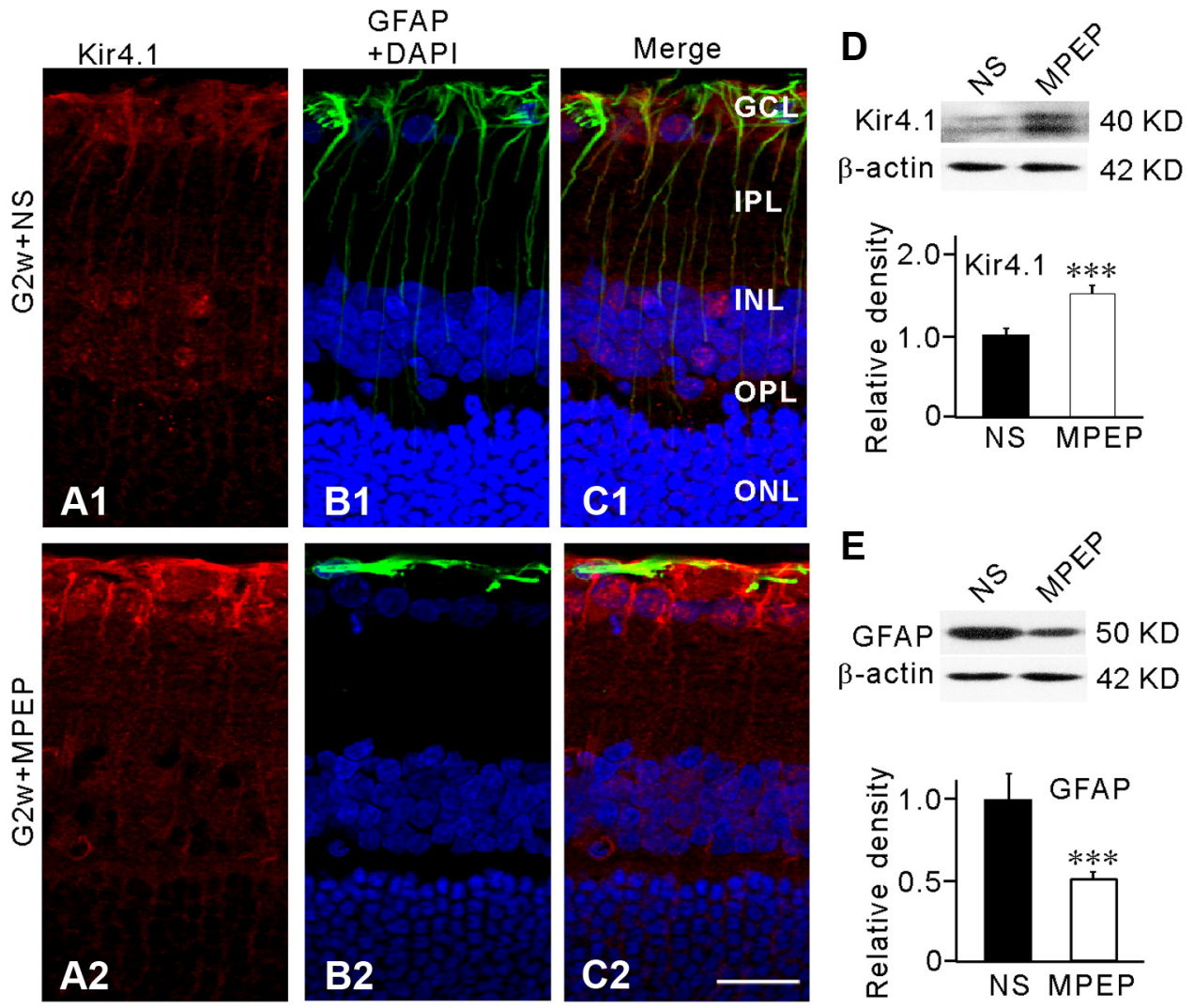

Figure 7. Selective mGluR5 antagonist MPEP modulates Kir4.1 protein expression and inhibits GFAP expression in COH model. MPEP ( $1 \mu \mathrm{M})$ or vehicle $(0.9 \%$ saline, NS) were injected into the vitreous space in a volume of $2 \mu \mathrm{l} 3 \mathrm{~d}$ before the operation. $\boldsymbol{A} \mathbf{1}, \mathbf{A 2}$, Immunofluorescence labeling showing the Kir4.1 protein expression in retinal vertical slices taken from NS- (A1) or MPEP- (A2) injected rat at second week (G2W) after the operation. B1, B2, Immunofluorescence labeling showing the GFAP protein expression and DAPI in the same slices as shown in $\boldsymbol{A}$ 1 and $\boldsymbol{A 2}$. C1, C2, Merged images of $\boldsymbol{A} \mathbf{1}$ and $\boldsymbol{B} \mathbf{1}, \boldsymbol{A} \mathbf{2}$ and $\boldsymbol{B} \mathbf{2}$, respectively. Scale bar, $20 \mu \mathrm{m}$. D, Representative Western blot analysis showing the Kir4.1 protein expression in NS- and MPEP-injected eyes (top). Bar chart summarizing the Kir4.1 protein expression in NS- and MPEP-injected eyes (below). $n=6,{ }^{* *} p<0.001$ versus NS. $E$, Representative Western blot analysis showing the GFAP protein expression in NS- and MPEP-injected eyes (top). Bar chart summarizing the GFAP protein expression in NS- and MPEP-injected eyes (below). $n=6,{ }^{* * *} p<0.001$ versus NS. All data were normalized to those obtained in the NS eyes.

further revealed that total Kir4.1 protein extracted from MPEP-injected retinas was increased to $152.1 \pm 9.5 \%$ of NSinjected retinas $(n=6, p<0.001$; Fig. $7 D)$, while total GFAP protein was decreased to $51.0 \pm 4.8 \%$ of NS-injected retinas $(n=6, p<0.001$; Fig. $7 E)$.

$\mathrm{Ca}^{2+}$-dependent $\mathrm{PLC} / \mathrm{IP}_{3}$-ryanodine/PKC signaling pathway mediates the DHPG effect

We explored the intracellular signaling pathway that links the activation of mGluR I and the down-regulation of Kir currents in isolated Müller cells. Activation of mGluR I may stimulate adenylyl cyclase, which is followed by the activation of cAMP-dependent protein kinase PKA. While this signaling pathway is responsible for the inhibition of outward $\mathrm{K}^{+}$currents in salamander Müller cells (Schwartz, 1993), it is unlikely involved in the DHPG-induced inhibition of Kir currents in rat Müller cells. Bath application of the adenylyl cyclase activator forskolin $(5 \mu \mathrm{M})$ did not change the Kir current amplitudes $(95.2 \pm 6.2 \%$ of pretreatment levels, $n=6, p=$ 0.90 ; Fig. $8 A$ ). In addition, inhibition of intracellular cAMP by the membrane-permeable cAMP inhibitor Rp-cAMP $(20 \mu \mathrm{M})$ hardly influenced the DHPG-induced suppression of Kir currents (Fig. $8 \mathrm{~B}$ ), and the peak current amplitudes obtained in the presence of Rp-cAMP were reduced to $52.8 \pm 7.2 \%$ of control $(n=5$, $p<0.001)$.

mGluR I is positively coupled to the PLC-PKC signaling pathway (Fagni et al., 2000; Hannan et al., 2001; Lüscher and Huber,
2010). To test possible involvement of PLC, isolated Müller cells were intracellularly dialyzed with U73122 (5 $\mu \mathrm{M})$, a phosphatidylinositol (PI)-PLC inhibitor, through recording pipettes for at least $5 \mathrm{~min}$, and then the effect of DHPG $(10 \mu \mathrm{M})$ on Kir currents was examined. In the presence of U73122, DHPG no longer suppressed Kir currents with the peak current amplitudes at $3 \mathrm{~min}$ after DHPG application being $95.7 \pm 10.7 \%$ of control $(n=5$, $p=0.88$; Fig. 8C). In contrast, intracellular dialysis with D609 (60 $\mu \mathrm{M}$ ), a phosphatidylcholine (PC)-PLC inhibitor, did not block the DHPG-induced decrease in Kir currents, with the average peak current amplitudes, obtained at 3 min after DHPG application, being $45.2 \pm 2.7 \%$ of control $(n=6, p<0.001$; Fig. $8 D)$. Furthermore, consistent with previous studies conducted in a variety of cells (Henry et al., 1996; Karle et al., 2002; Park et al., 2005), intracellular dialysis with Bis IV $(5 \mu \mathrm{M})$, a specific PKC inhibitor, fully eliminated the suppression of Kir currents by DHPG (101.2 $\pm 2.3 \%$ of control, $n=6, p=0.82$; Fig. $8 E)$. Internal dialysis with chelerythrine chloride $(5 \mu \mathrm{M})$, another PKC inhibitor, yielded similar results (104.2 $\pm 5.1 \%$ of control, $n=9$, $p=0.92$; Fig. $8 F$ ). These results suggest the involvement of the PLC-PKC signaling pathway in the DHPG effect on Kir currents.

Activation of mGluR I may increase intracellular $\mathrm{Ca}^{2+}$ concentrations $\left(\left[\mathrm{Ca}^{2+}\right]_{\mathrm{i}}\right)$ through $\mathrm{IP}_{3^{-}}$and/or ryanodine-sensitive $\mathrm{Ca}^{2+}$ stores in neurons (Fagni et al., 2000; Morikawa et al., 2003; Sohn et al., 2011). When recording pipettes were filled with in- 
ternal $\mathrm{Ca}^{2+}$-free solution containing 10 mM BAPTA, a calcium chelator, bath application of $10 \mu \mathrm{M}$ DHPG did not change the Kir currents (Fig. 9A), suggesting the involvement of intracellular calcium stores. Furthermore, by blocking $\mathrm{IP}_{3}$ receptors with intracellular dialysis of heparin $(5 \mathrm{mg} / \mathrm{ml})$, a competitive $\mathrm{IP}_{3}$ receptor antagonist, DHPG of $10 \mu \mathrm{M}$ caused a moderate suppression of the Kir currents, which was much less than that obtained without dialysis of heparin $(84.3 \pm 6.2 \%$ vs $39.1 \pm 5.9 \%$ of control, $n=5, p=$ 0.024) (Fig. 9B). Experiments with caffeine, a ryanodine receptor agonist, yielded similar results. Bath application of $1 \mathrm{~mm}$ caffeine reduced the Kir currents by $18.2 \pm 6.8 \%(n=6)$ (Fig. 9C). It seems that activation of mGluR I-induced increase in $\left[\mathrm{Ca}^{2+}\right]_{\mathrm{i}}$ in rat Müller cells could be due to $\mathrm{Ca}^{2+}$ release from both $\mathrm{IP}_{3}$ - and ryanodine-sensitive $\mathrm{Ca}^{2+}$ stores.

Changes in calcium/calmodulindependent protein kinase II (CaMKII) activity, which have been reported in various types of central neurons (Choe and Wang, 2001; Mockett et al., 2011), were unlikely involved in DHPG-induced suppression of Kir currents in Müller cells. Bath application of CaMKII inhibitors $\mathrm{KN}-62(5 \mu \mathrm{M}) / \mathrm{KN}-93(10 \mu \mathrm{M}) \mathrm{did}$ not change the Kir currents. In the presence of $\mathrm{KN}-62 / \mathrm{KN}-93$, addition of $10 \mu \mathrm{M}$ DHPG suppressed the Kir currents, which was not much different from that observed in NS. Following application DHPG for $300 \mathrm{~s}$, the average current amplitudes were $49.7 \pm 16.3 \%$ (for $\mathrm{KN}-62$, $n=5, p<0.001$ ) (Fig. 10A) and $44.8 \pm$ $5.5 \%$ of the level obtained before DHPG application (for KN-93, $n=9, p<0.001$ ) (Fig. 10B).

\section{Discussion}

\section{Kir4.1 channels in rat Müller cells}

Rat Müller cells express various subtypes of Kir channels, including Kir2.1, Kir4.1, and Kir 5.1 (Kofuji et al., 2002; Ishii et al., 2003; Iandiev et al., 2006; Wurm et al., 2006). These channels with high $\mathrm{K}^{+}$permeability are essential for Müller cells to maintain homeostasis of $\left[\mathrm{K}^{+}\right]_{\mathrm{o}}$ (Kofuji et al., 2002; Bringmann et al., 2006). In the present study, the currents evoked by voltage steps/ramps recorded from isolated rat Müller cells were highly dependent on $\left[\mathrm{K}^{+}\right]_{\mathrm{o}}$ (Fig. $1 \mathrm{~B}$ ), exhibiting a weakly rectifying $I-V$ relationship (Fig. 1D,E). Moreover, the currents were largely suppressed by $\mathrm{Ba}^{2+}$. All these results suggest that Kir4.1 may be a primary protein component mediating the currents (Kofuji et al., 2002; Bringmann et al., 2006). It should be noted that the currents recorded under our experimental conditions may involve a smaller component contributed by members of the tandem-pore domain (2P-domain) $\mathrm{K}^{+}$channel, such as TASK-1, TASK-2, and TASK-3, which are expressed in rat Müller cells (Kofuji et al., 2002; Skatchkov et al., 2006).
B<smiles>C1CCCCC1</smiles>

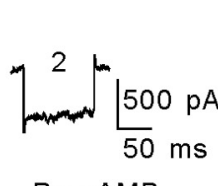

C

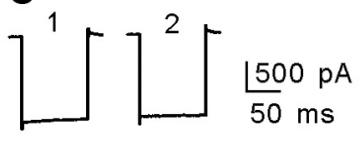

Rp-cAMP
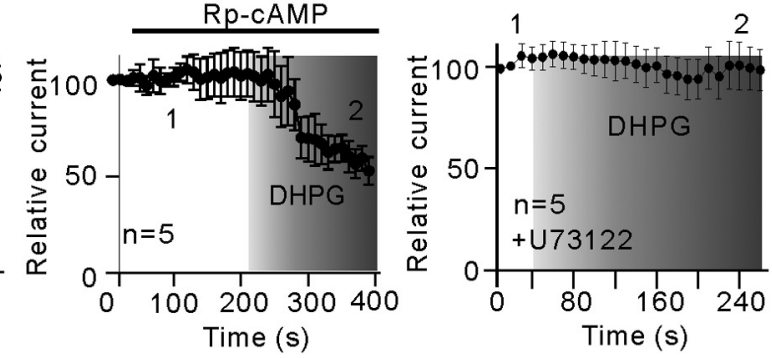

E

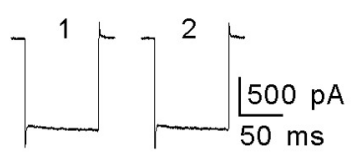

$\mathbf{F}$
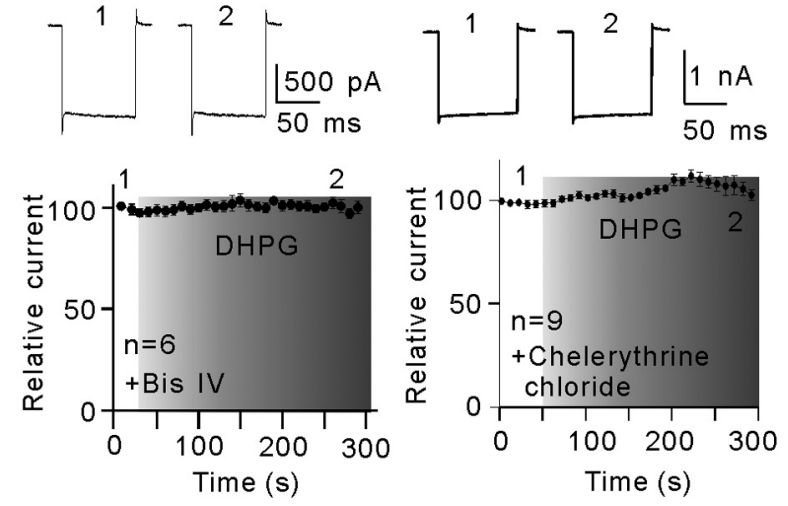

Figure 8. PLC-PKC signaling pathway mediates the DHPG-induced inhibition of Kir currents. $\boldsymbol{A}$, Plot of Kir inward currents as a function 列 作 $160 \mathrm{mV}$ as a function of time. Rp-CAMP $(20 \mu \mathrm{m})$ failed to block the DHPG-induced reduction in Kir current amplitudes. The representative 作 representative current traces (top) are taken from the time points as indicated. $\boldsymbol{E}$, Kir current as a function of time, showing that intracellular pre-dialysis of Bis IV $(5 \mu \mathrm{m})$ completely eliminated the DHPG effect on Kir currents $(n=6)$. The representative current traces are shown at the top. $\boldsymbol{F}$, Kir current as a function of time, showing that extracellular application of chelerythrine chloride $(5 \mu \mathrm{m})$ completely eliminated the DHPG effect on Kir currents $(n=9)$ ). All the current amplitudes are normalized to the amplitude of the first evoked event.

Kir channels and Müller cell gliosis in experimental glaucoma Although down-regulation or loss of Müller cell Kir currents commonly occurs in many retinal injuries and diseases, there is only limited evidence, indicating that this is the case in glaucoma and experimental glaucoma (Francke et al., 1997; Bolz et al., 2008). In our rat $\mathrm{COH}$ model we clearly revealed that Kir currents were significantly reduced, which is consistent with the observation in patients with secondary glaucoma, showing large decrease or loss of Kir currents of Müller cells (Francke et al., 1997). The decreased Kir currents may be due to the reduced expression of Kir4.1 proteins, as shown by Western blotting (Fig. 3G). Meanwhile, a progressive increase in GFAP expression in Müller cells was observed (Fig. $3 H$ ), suggesting the occurrence of Müller cell gliosis. We tend to consider a possibility that the enhanced GFAP expression may be a consequence of the reduced activity of Kir4.1 channels. A strong argument in favor of this possibility is that intravitreal injection of $\mathrm{BaCl}_{2}$, which is supposed to block Kir channels, increased GFAP expression in normal retina and no further increase in GFAP expression was seen even when mGluR I was activated by DHPG (Fig. 6). It should be noted that during 4-6 weeks after the operation the inhibition of Kir currents was attenuated (Fig. 2), but GFAP expression did not match such 


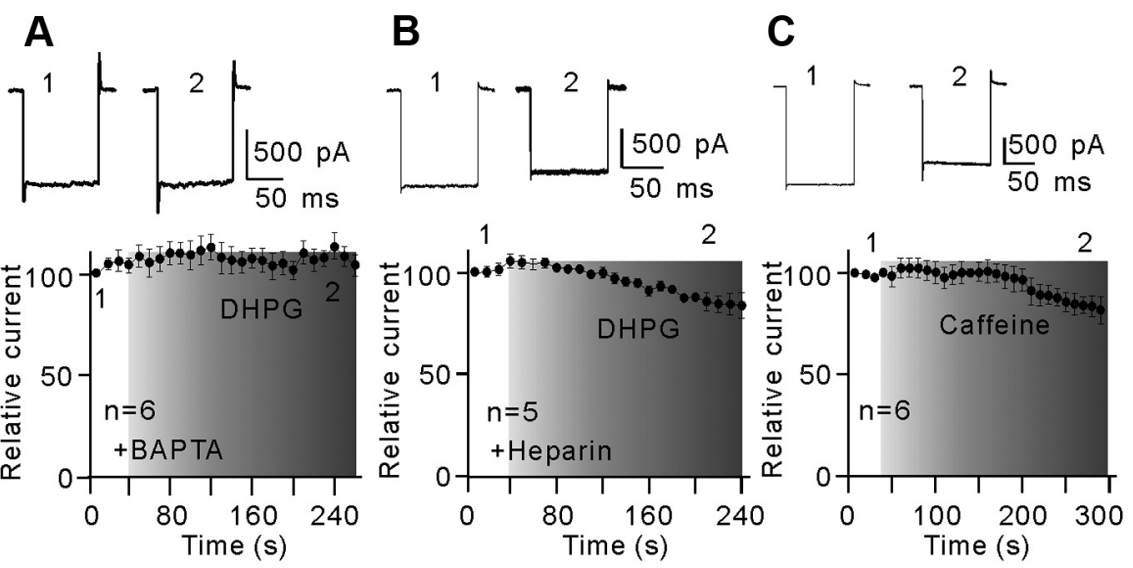

Figure 9. $\quad \mathrm{Ca}^{2+}$ release from intracellular stores is involved in the DHPG effect on Kir currents. $A$, Plot of Kir inward currents as a function of time, showing that internal preperfusion of BAPTA $(10 \mathrm{~mm})$ to chelate intracellular $\mathrm{Ca}^{2+}$ eliminated fully the DHPG effect on Kir currents $(n=6)$. The representative current traces recorded at different time points are shown at the top as indicated. $\boldsymbol{B}$, Plot of Kir inward currents as a function of time, showing that intracellular preinfusion of heparin $(5 \mathrm{mg} / \mathrm{ml})$ partially rescued the DHPG-induced inhibition in Kir currents $(n=5)$. The representative current traces (top) are taken from the time points as indicated. C, Plot of Kir inward currents as a function of time, showing that extracellular perfusion of caffeine $(1 \mathrm{~mm})$ induced a minor reduction in Kir currents with a long time delay $(n=6)$. The representative current traces are shown at the top. All the current amplitudes are normalized to the amplitude of the first evoked event.

A
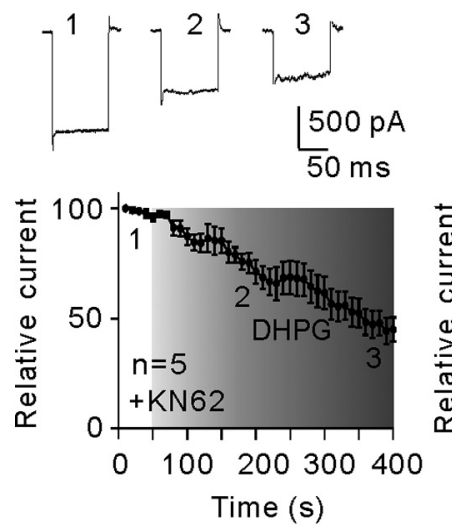

Figure 10. No involvement of CaMKII in DHPG-induced inhibition of Kir currents. $\boldsymbol{A}, \boldsymbol{B}$, Plots of Kir currents as a function of time, showing that extracellular application of CaMKII inhibitors KN-62 (5 $\mu \mathrm{m})(\boldsymbol{A}, n=5)$ or KN-93 (10 $\mu \mathrm{M})(\boldsymbol{B}, n=9)$ did not block the DHPG effect on Kir currents. The representative current traces (top) are taken from the time points as indicated. All the current amplitudes are normalized to the amplitude of the first evoked event.

changes. A possible explanation is that Müller cell gliosis lasts for a long period of time even when the stimulating factor (changes in Kir currents) is attenuated. In retinal diseases other than glaucoma it has been shown that alteration of Kir currents may be associated with the extent of gliosis. That is, no significant change in Kir currents is found in some slow retinal degenerative diseases, such as observed in DBA/2J mice (Bolz et al., 2008), where Müller cells undergo a nonproliferative gliosis, moderate reduction of Kir currents is seen in conservative gliosis, and dramatic down-regulation is related to proliferative gliosis (Bringmann et al., 2000).

It was previously reported that the expression of Kir4.1 protein in Müller cells was strongly downregulated by retinal ischemiareperfusion, while the Kir2.1 protein expression was not altered (Iandiev et al., 2006). In the present study, the weakly rectifying $I-V$ relationships of the Kir channel currents and the suppression of the currents by $\mathrm{Ba}^{2+}$ all suggest that Kir4.1 may be a primary compo- nent mediating these currents in our conditions (Fig. 1). Moreover, in glaucomatous eyes the decrease in Kir4.1 protein expression was observed in all parts of the Müller cells (Fig. 3), while the changes caused by ischemia occurred in specific regions of Müller cells (Iandiev et al., 2006).

A question that remains to be addressed is how activation of mGluR I leads to down-regulation of Kir4.1 protein expression in Müller cells. There may be two possible pathways. The first possible pathway could be that persistent glutamate exposure activates mGluR I-mediated intracellular signaling, which may decrease the mRNA level of Kir4.1 by downregulating transcription. It has been shown that retinal ischemia-induced decrease in Kir4.1 protein expression is accompanied by a down-regulation of the mRNA level for Kir4.1 (Iandiev et al., 2006). An alternative possibility is that activation of mGluR I increases the activity of PKC, thus leading to Kir4.1 protein internalization. Although there are no data about Kir4.1 channel internalization, PKC-dependent ATPsensitive potassium channel $\left(\mathrm{K}_{\mathrm{ATP}}\right)$ internalization and lysosomal degradation have been reported (Hu et al., 2003; Manna et al., 2010; Aziz et al., 2012).

Activation of mGluR I may contribute to Müller cell gliosis by suppressing Kir channels

As shown in Figure 4, activation of mGluR5 by DHPG suppressed Kir channels. Unlike mGluR I receptor-mediated regulation of outward $\mathrm{K}^{+}$currents in Müller cells due to activation of the cAMP-PKA pathway (Schwartz, 1993), mGluR I-mediated suppression of Kir currents in rat Müller cells depends on the intracellular $\mathrm{Ca}^{2+}$-dependent PI-PLC/PKC signaling pathway, but without the involvement of PKA and CaMKII signaling pathways. Meanwhile, activation of mGluR I enhanced the expression of GFAP in Müller cells. It was evident that the changes in Kir and GFAP expression induced by mGluR I activation mimicked the changes induced by $\mathrm{COH}$. Moreover, as shown in Figure 6, suppression of Kir channels by $\mathrm{Ba}^{2+}$ blocked DHPG-induced Müller cells gliosis. The enhanced Kir4.1 expression and the reduced GFAP expression in Müller cells by MPEP in the $\mathrm{COH}$ rats are suggestive of the involvement of mGluR5 in Müller cell gliosis (Fig. 7). It is recently shown that functional expression of Kir4.1 is sufficient to inhibit proliferation in glioma cells by shifting the cells from G2/M phase into the quiescent G0/G1 stage of the cell cycle (Higashimori and Sontheimer, 2007). It should be indicated that whether glutamate levels are increased in glaucomatous eyes is a controversial issue (Levkovitch-Verbin et al., 2002; Dreyer et al., 1996). However, growing evidence suggests that the excess of extracellular glutamate may be a potential risk factor for retinal injury in glaucoma, as evidenced by prevention of ganglion cell death due to the administration of NMDA receptor antagonists MK-801/memantine in rat experimental glaucoma models (Guo et al., 2006; Salt and Cordeiro, 2006; Seki and Lipton, 2008). Indeed, glutamate transporters were found to be significantly reduced in rat glaucoma models, indicating frustration of the effective buffering of extracellular glutamate (Vorwerk et al., 2000; Martin et al., 2002; Harada et al., 2007). In case extracellular 
glutamate levels are elevated in glaucoma, mGluR 5 may be overactivated, thus causing a suppression of Kir channels of Müller cells, which results in enhanced GFAP expression (gliosis).

Elevated retinal glutamate levels may also lead to an overactivation of NMDA receptors in general. However, many studies show no significant glutamate-induced $\mathrm{Ca}^{2+}$ transient in mammalian (rat, guinea pig) retinal Müller cells (Newman and Zahs, 1997; Bringmann et al., 2002b; Newman, 2005; Rillich et al., 2009). Because Müller cells have a relatively hyperpolarized resting membrane potential, the NMDA channels in these cells may be blocked by $\mathrm{Mg}^{2+}$ under physiological conditions.

\section{Pathophysiological implication of Müller cell gliosis in glaucoma}

Effects caused by Müller cell gliosis on retinal neurons may be cytoprotective or cytotoxic (for review, see Bringmann et al., 2006). Among them, Müller cell gliosis in experimental glaucoma may result in dysregulation of the glio-neuronal interaction in the retina (Bringmann et al., 2000; Bringmann and Reichenbach, 2001). It is also noteworthy that the reduced activity of Kir channels due to the overactivation of mGluR I may lead to a depolarization of Müller cells, thus reducing glutamate uptake of Müller cells, as glutamate transport into the cells is strongly voltagedependent (Sarantis and Attwell, 1990). Such a change in glutamate transport could cause an increased accumulation of extracellular glutamate, resulting in a further activation of mGluR I. Moreover, down-regulation of Kir channels may also change the water transport into the cells by impairing spatial potassium buffering, which is suggested to contribute to the development of retinal edema (Nagelhus et al., 1999; Pannicke et al., 2004). The present study provides evidence, suggesting that appropriate reduction of retinal mGluR I activity in glaucoma, which could alleviate Müller cell gliosis, may be an effective way for preventing the loss of retinal ganglion cells. It should be noted that our glaucoma model, exhibiting a rapid increase in IOP, is different from the one in DBA/2J mice that have a much longer time course of IOP elevation before elevation can be seen. Whether mechanisms underlying Müller cell gliosis in a chronic glaucoma model, like in DBA/2J mice, which is more pertinent to human glaucoma, are similar or different needs to be further explored.

\section{References}

Aziz Q, Thomas AM, Khambra T, Tinker A (2012) Regulation of the ATPsensitive potassium channel subunit, Kir6.2, by a $\mathrm{Ca}^{2+}$-dependent protein kinase C. J Biol Chem 287:6196-6207.

Bolz S, Schuettauf F, Fries JE, Thaler S, Reichenbach A, Pannicke T (2008) $\mathrm{K}^{+}$currents fail to change in reactive retinal glial cells in a mouse model of glaucoma. Graefes Arch Clin Exp Ophthalmol 246:1249-1254.

Bringmann A, Reichenbach A (2001) Role of Muller cells in retinal degenerations. Front Biosci 6:E72-E92.

Bringmann A, Francke M, Pannicke T, Biedermann B, Kodal H, Faude F, Reichelt W, Reichenbach A (2000) Role of glial $\mathrm{K}^{+}$channels in outogeny and gliosis: a hypothesis based upon studies on Müller cells. Glia 29:35-44.

Bringmann A, Pannicke T, Uhlmann S, Kohen L, Wiedemann P, Reichenbach A (2002a) Membrane conductance of Müller glial cells in proliferative diabetic retinopathy. Can J Ophthalmol 37:221-227.

Bringmann A, Pannicke T, Weick M, Biedermann B, Uhlmann S, Kohen L, Wiedemann P, Reichenbach A (2002b) Activation of P2Y receptors stimulates potassium and cation currents in acutely isolated human Muller (glial) cells. Glia 37:139-152.

Bringmann A, Pannicke T, Grosche J, Francke M, Wiedemann P, Skatchkov SN, Osborne NN, Reichenbach A (2006) Müller cells in the health and diseased retina. Prog Retin Eye Res 25:397-424.

Bringmann A, Iandiev I, Pannicke T, Wurm A, Hollborn M, Wiedemann P, Osborne NN, Reichenbach A (2009) Cellular signaling and factors in- volved in Müller cell gliosis: neuroprotective and detrimental effects. Prog Retin Eye Res 28:423-451.

Butt AM, Kalsi A (2006) Inwardly rectifying potassium channels (Kir) in central nervous system glia: a special role for Kir4.1 in glial functions. J Cell Mol Med 10:33-44.

Caraci F, Battaglia G, Sortino MA, Spampinato S, Molinaro G, Copani A, Nicoletti F, Bruno V (2012) Metabotropic glutamate receptors in neurodegeneration/neuroprotection: Still a hot topic? Neurochem Int. Advance online publication. doi:10.1016/j.neuint.2012.01.017.

Chen J, Miao Y, Wang XH, Wang Z (2011) Elevation of p-NR2A ${ }^{\mathrm{S1232}}$ by $\mathrm{Cdk} 5 / \mathrm{p} 35$ contributes to retinal ganglion cell apoptosis in a rat experimental glaucoma model. Neurobiol Dis 43:455-464.

Choe ES, Wang JQ (2001) Group I metabotropic glutamate receptors control phosphorylation of CREB, Elk-1 and ERK via a CaMKII-dependent pathway in rat striatum. Neurosci Lett 313:129-132.

Dreyer EB, Zurakowski D, Schumer RA, Podos SM, Lipton SA (1996) Elevated glutamate levels in the vitreous body of humans and monkeys with glaucoma. Arch Ophthalmol 114:299-305.

Fagni L, Chavis P, Ango F, Bockaert J (2000) Complex interactions between mGluRs, Intracellular $\mathrm{Ca}^{2+}$ stores and ion channels in neurons. Trends Neurosci 23:80-88.

Francke M, Pannicke T, Biedermann B, Faude F, Wiedemann P, Reichenbach A, Reichelt W (1997) Loss of inwardly rectifying potassium currents by human retinal glial cells in diseases of the eye. Glia 20:210-218.

Francke M, Faude F, Pannicke T, Bringmann A, Eckstein P, Reichelt W, Wiedemann P, Reichenbach A (2001) Electrophysiology of rabbit Müller (glial) cells in experimental retinal detachment and PVR. Invest Ophthalmol Vis Sci 42:1072-1079.

Goureau O, Régnier-Ricard F, Courtois Y (1999) Requirement for nitric oxide in retinal neuronal cell death induced by activated Müller glial cells. J Neurochem 72:2506-2515.

Guo L, Salt TE, Maass A, Luong V, Moss SE, Fitzke FW, Cordeiro MF (2006) Assessment of neuroprotective effects of glutamate modulation on glaucoma-related retinal ganglion cell apoptosis in vivo. Invest Ophthalmol Vis Sci 47:626-633.

Hannan AJ, Blakemore C, Katsnelson A, Vitalis T, Huber KM, Bear M, Roder J, Kim D, Shin HS, Kind PC (2001) PLC-betal, activated via mGluRs, mediates activity-dependent differentiation in cerebral cortex. Nat Neurosci 4:282-288.

Harada T, Harada C, Nakamura K, Quah HM, Okumura A, Namekata K, Saeki T, Aihara M, Yoshida H, Mitani A, Tanaka K (2007) The potential role of glutamate transporters in the pathogenesis of normal tension glaucoma. J Clin Invest 117:1763-1770.

Henry P, Pearson WL, Nichols CG (1996) Protein kinase C inhibition of cloned inward rectifier (HRK1/KIR2.3) $\mathrm{K}^{+}$channels expressed in Xenopus oocytes. J Physiol 495:681-688.

Higashimori H, Sontheimer H (2007) Role of Kir4.1 channels in growth control of glia. Glia 55:1668-1679.

Hu K, Huang CS, Jan YN, Jan LY (2003) ATP-sensitive potassium channel traffic regulation by adenosine and protein kinase C. Neuron 38:417-432.

Iandiev I, Tenckhoff S, Pannicke T, Biedermann B, Hollborn M, Wiedemann P, Reichenbach A, Bringmann A (2006) Differential regulation of Kir4.1 and Kir2.1 expression in the ischemic rat retina. Neurosci Lett 396:97-101.

Inman DM, Horner PJ (2007) Reactive nonproliferative gliosis predominates in a chronic mouse model of glaucoma. Glia 55:942-953.

Ishii M, Horio Y, Tada Y, Hibino H, Inanobe A, Ito M, Yamada M, Gotow T, Uchiyama Y, Kurachi Y (1997) Expression and clustered distribution of an inwardly rectifying potassium channel, KAB-2/Kir4.1, on mammalian retinal Müller cell membrane: their regulation by insulin and laminin signals. J Neurosci 17:7725-7735.

Ishii M, Fujita A, Iwai K, Kusaka S, Higashi K, Inanobe A, Hibino H, Kurachi Y (2003) Differential expression and distribution of Kir5.1 and Kir4.1 inwardly rectifying $\mathrm{K}^{+}$channels in retina. Am J Physiol Cell Physiol 285:C260-C267.

Karle CA, Zitron E, Zhang W, Wendt-Nordahl G, Kathöfer S, Thomas D, Gut B, Scholz E, Vahl CF, Katus HA, Kiehn J (2002) Human cardiac inwardly-rectifying $\mathrm{K}^{+}$channel $\operatorname{Kir}(2.1 \mathrm{~b})$ is inhibited by direct protein kinase C-dependent regulation in human isolated cardiomyocytes and in an expression system. Circulation 106:1493-1499.

Kashiwagi K, Iizuka Y, Araie M, Suzuki Y, Tsukahara S (2001) Effects of 
retinal glial cells on isolated rat retinal ganglion cells. Invest Ophthalmol Vis Sci 42:2686-2694.

Kofuji P, Biedermann B, Siddharthan V, Raap M, Iandiev I, Milenkovic I, Thomzig A, Veh RW, Bringmann A, Reichenbach A (2002) Kir potassium channel subunit expression in retinal glial cells: implications for spatial potassium buffering. Glia 39:292-303.

Lau A, Tymianski M (2010) Glutamate receptors, neurotoxicity and neurodegeneration. Pflugers Arch 460:525-542.

Levkovitch-Verbin H, Martin KR, Quigley HA, Baumrind LA, Pease ME, Valenta D (2002) Measurement of amino acid levels in the vitreous humor of rats after chronic intraocular pressure elevation or optic nerve transection. J Glaucoma 11:396-405.

Lüscher C, Huber KM (2010) Group 1 mGluR-dependent synaptic longterm depression: mechanisms and implications for circuitry and disease. Neuron 65:445-459.

Manna PT, Smith AJ, Taneja TK, Howell GJ, Lippiat JD, Sivaprasadarao A (2010) Constitutive endocytic recycling and protein kinase C-mediated lysosomal degradation control $\mathrm{K}_{\mathrm{ATP}}$ channel surface density. J Biol Chem 285:5963-5973.

Martin KR, Levkovitch-Verbin H, Valenta D, Baumrind L, Pease ME, Quigley HA (2002) Retinal glutamate transporter changes in experimental glaucoma and after optic nerve transection in the rat. Invest Ophthalmol Vis Sci 43:2236-2243.

Mockett BG, Guévremont D, Wutte M, Hulme SR, Williams JM, Abraham WC (2011) Calcium/calmodulin-dependent protein kinase II mediates group I metabotropic glutamate receptor-dependent protein synthesis and long-term depression in rat hippocampus. J Neurosci 31:7380-7391.

Morikawa H, Khodakhah K, Williams JT (2003) Two intracellular pathways mediate metabotropic glutamate receptor-induced $\mathrm{Ca}^{2+}$ mobilization in dopamine neurons. J Neurosci 23:149-157.

Nagelhus EA, Horio Y, Inanobe A, Fujita A, Haug FM, Nielsen S, Kurachi Y, Ottersen OP (1999) Immunogold evidence suggests that coupling of $\mathrm{K}^{+}$siphoning and water transport in rat retinal Müller cells is mediated by a coenrichment of Kir4.1 and AQP4 in specific membrane domains. Glia 26:47-54.

Naka M, Kanamori A, Negi A, Nakamura M (2010) Reduced expression of aquaporin-9 in rat optic nerve head and retina following elevated intraocular pressure. Invest Ophthalmol Vis Sci 51:4618-4626.

Newman EA (1993) Inward-rectifying potassium channels in retinal glial (Müller) cells. J Neurosci 13:3333-3345.

Newman EA (2005) Calcium increases in retinal glial cells evoked by lightinduced neuronal activity. J Neurosci 25:5502-5510.

Newman EA, Zahs KR (1997) Calcium waves in retinal glial cells. Science 275:844-847.

Nicoletti F, Bruno V, Catania MV, Battaglia G, Copani A, Barbagallo G, Ceña V, Sanchez-Prieto J, Spano PF, Pizzi M (1999) Group-I metabotropic glutamate receptors: hypotheses to explain their dual role in neurotoxicity and neuroprotection. Neuropharmacology 38:1477-1484.

Pannicke T, Faude F, Reichenbach A, Reichelt W (2000) A function of delayed rectifier potassium channels in glial cells: maintenance of an auxiliary membrane potential under pathological conditions. Brain Res 862:187-193.

Pannicke T, Iandiev I, Uckermann O, Biedermann B, Kutzera F, Wiedemann P, Wolburg H, Reichenbach A, Bringmann A (2004) A potassium channel-linked mechanism of glial cell swelling in the postischemic retina. Mol Cell Neurosci 26:493-502.

Pannicke T, Iandiev I, Wurm A, Uckermann O, vom Hagen F, Reichenbach A, Wiedemann P, Hammes HP, Bringmann A (2006) Diabetes alters osmotic swelling and membrane characteristics of glial cells in rat retina. Diabetes 55:633-639.
Park WS, Han J, Kim N, Youm JB, Joo H, Kim HK, Ko JH, Earm YE (2005) Endothelin-1 inhibits inward rectifier $\mathrm{K}^{+}$channels in rabbit coronary arterial smooth muscle cells through protein kinase C. J Cardiovasc Pharmacol 46:681-689.

Rillich K, Gentsch J, Reichenbach A, Bringmann A, Weick M (2009) Light stimulation evokes two different calcium responses in Müller glial cells of the guinea pig retina. Eur J Neurosci 29:1165-1176.

Salt TE, Cordeiro MF (2006) Glutamate excitotoxicity in glaucoma: throwing the baby out with the bathwater? Eye 20:730-731.

Sarantis M, Attwell D (1990) Glutamate uptake in mammalian retinal glia is voltage- and potassium-dependent. Brain Res 516:322-325.

Schwartz EA (1993) L-glutamate conditionally modulates the $\mathrm{K}^{+}$current of Muller glial cells. Neuron 10:1141-1149.

Seki M, Lipton SA (2008) Targeting excitotoxic/free radical signaling pathways for therapeutic intervention in glaucoma. Prog Brain Res 173:495-510.

Skatchkov SN, Eaton MJ, Shuba YM, Kucheryavykh YV, Derst C, Veh RW, Wurm A, Iandiev I, Pannicke T, Bringmann A, Reichenbach A (2006) Tandem-pore domain potassium channels are functionally expressed in retinal (Müller) glial cells. Glia 53:266-276.

Sofroniew MV (2005) Reactive astrocytes in neural repair and protection. Neuroscientist 11:400-407.

Sohn JW, Yu WJ, Lee D, Shin HS, Lee SH, Ho WK (2011) Cyclic ADP ribose-dependent $\mathrm{Ca}^{2+}$ release by group I metabotropic glutamate receptors in acutely dissociated rat hippocampal neurons. PLoS One 6:e26625.

Tada Y, Horio Y, Kurachi Y (1998) Inwardly rectifying $\mathrm{K}^{+}$channel in retinal Müller cells: comparison with the KAB-2/Kir4.1 channel expressed in HEK293T cells. Jpn J Physiol 48:71-80.

Tezel G, Wax MB (2003) Glial modulation of retinal ganglion cell death in glaucoma. J Glaucoma 12:63-68.

Tezel G, Li LY, Patil RV, Wax MB (2001) Tumor neurosis factor-alpha and its receptor-1 in the retina of normal and glaucomatous eyes. Invest Ophthalmol Vis Sci 42:1787-1794.

Vorwerk CK, Naskar R, Schuettauf F, Quinto K, Zurakowski D, Gochenauer G, Robinson MB, Mackler SA, Dreyer EB (2000) Depression of retinal glutamate transporter function leads to elevated intravitreal glutamate levels and ganglion cell death. Invest Ophthalmol Vis Sci 41:3615-3621.

Wang X, Tay SS, Ng YK (2000) An immunohistochemical study of neuronal and glial cell reactions in retinae of rats with experimental glaucoma. Exp Brain Res 132:476-484.

Woldemussie E, Wijono M, Ruiz G (2004) Müller cell response to laserinduced increase in intraocular pressure in rats. Glia 47:109-119.

Wu J, Zhang S, Sun X (2010) Neuroprotective effect of upregulated sonic Hedgehog in retinal ganglion cells following chronic ocular hypertension. Invest Ophthalmol Vis Sci 51:2986-2992.

Wurm A, Pannicke T, Iandiev I, Wiedemann P, Reichenbach A, Bringmann A (2006) The developmental expression of $\mathrm{K}^{+}$channels in retinal glial cells is associated with a decrease of osmotic cell swelling. Glia 54:411-423.

Xue LP, Lu J, Cao Q, Hu S, Ding P, Ling EA (2006) Müller glial cells express nestin coupled with glial fibrillary acidic protein in experimentally induced glaucoma in the rat retina. Neuroscience 139:723-732.

Yang XF, Miao Y, Ping Y, Wu HJ, Yang XL, Wang Z (2011) Melatonin inhibits tetraethylammonium-sensitive potassium channels of rod ON type bipolar cells via MT2 receptors in rat retina. Neuroscience 173:19-29.

Zhang S, Wang H, Lu Q, Qing G, Wang N, Wang Y, Li S, Yang D, Yan F (2009) Detection of early neuron degeneration and accompanying glial responses in the visual pathway in a rat model of acute intraocular hypertension. Brain Res 1303:131-143.

Zhao WJ, Zhang M, Miao Y, Yang XL, Wang Z (2010) Melatonin potentiates glycine currents through a PLC/PKC signaling pathway in rat retinal ganglion cells. J Physiol 588:2605-2619. 